\title{
FERNANDO GIL: ALUCINAÇÃO, IDENTIDADE E EXPERIÊNCIA ESTÉTICA
}

\author{
José Manuel Heleno \\ CEFI - UCP
}

1. A posição anti historicista de Fernando Gil no que concerne à filosofia é patente pelo menos desde Provas. ${ }^{1}$ De tal modo, que o autor chega mesmo a escrever que nem sequer é necessário "reativar" as perspetivas filosóficas, forçando atualizações hermenêuticas, pois os textos são suficientemente profundos tal como se apresentam. Ora, a convicção de que não deixará de existir uma redescoberta da filosofia é uma constante em toda a reflexão de Fernando Gil. É por isso que permanece, ao longo de toda a sua obra, uma necessidade de revisitar autores e controvérsias, de repensar argumentos e de mostrar o que há neles de insaturável. ${ }^{2}$

Como se emoldura Provas? É preciso fazer o rastreio das tradições (filosofia, retórica, direito) da prova, a sua epistemologia e a relação entre prova e justificação. São, por isso, convocados diferentes tipos de saberes. Todavia, o que caracteriza a reflexão de Gil é o reenvio de uns saberes para outros. Trata-se de um conhecimento em rede, que salienta a pertinência dos problemas a partir de outros problemas/soluções que se encontram noutros saberes. ${ }^{3}$ No entanto, já se desenha em Provas a questão da crença associada à justificação da prova. Assim, defendem alguns que a regressão ao infinito da justificação da prova mostra que não há crenças últimas. Em contraposição

1 Fernando Gil, Provas. Lisboa: Imprensa Nacional-Casa da Moeda, 1986.

${ }^{2}$ Cf. Fernando Gil, La conviction, Paris: Flammarion, 2000. Onde se escreve: "Esta investigação repousa sobre um certo tipo de diálogo com a história da filosofia. Esta é de qualquer modo concebida como perene" (p. 21).

${ }^{3}$ Cf. Fernando Gil, "Cruzamentos da Enciclopédia". Prelo, Revista da Imprensa Nacional-Casa da Moeda, Lisboa, 1986. 
a esta visão cética, há os que consideram a existência de crenças intrinsecamente credíveis. Como escreve Fernando Gil no início de Provas: "a prova inscreve-se na temática mais ampla da justificação". E acrescenta que "não é um dispositivo único e unívoco".

A verdade é que podemos aventurar-nos a descobrir uma espécie de "gramática" giliana que se manterá ao longo da sua reflexão filosófica. A questão do assentimento aparece em Provas mas regressa em força no Tratado da Evidência. Assim, tanto a noção de prova como de evidência reenvia para crença, justificação, assentimento e outras noções. A ideia - inevitável para que a inteligibilidade dos problemas e das soluções aconteça (em filosofia, ciência e senso comum) - é este reenvio para conceitos que estão incumbidos de esclarecer outros. Há assim conceitos prioritários na apreensão inteligivel. Mas serão eles mais esclarecedores? Certamente. Mas que fará com que sejam mais esclarecedores? Que inteligibilidade é essa? Embora ultrapasse o objetivo do nosso ensaio, assinalemos a importância da noção de pregnância tal como a desenvolve René Thom. ${ }^{4}$

2. Outro termo desta cadeia conceptual é o de convicção. Vale a pena referir que a encontramos já em Provas: "A prova é indissociável de um assentimento que apresenta graus e o problema que coloca é, pois, o seguinte: em que condições e segundo que critérios um juízo ou uma teoria devem ser declarados suficientemente justificados, de modo a suscitarem convicção?" Também se encontra a noção de evidência noutro trecho (embora ela se dissemine por todo o texto): 'Na realidade, a inteligibilidade é uma noção compósita, cujos índices (que não são eles próprios nem imediatamente claros nem inteiramente distintos) se chamam, pelo menos, objetividade, causalidade, coerência, continuidade, simplicidade, operatividade, ajustamento... resultando na «evidência» que apresenta uma teoria". 6

Paralelo a este anseio de compreender os conceitos filosóficos e de apurar reflexões ou controvérsias epistemológicas, surge na obra de Fernando Gil outro tipo de preocupações que podem ser ilustradas por aquilo que, no seu último livro, referiu a propósito da música. ${ }^{7} \mathrm{De}$ facto, a ideia de que "o registo pulsional é pré-discursivo - pese a Jacques Lacan - e a estrutura, a operação,

4 Cf. René Thom, "Que significa compreender?". In: Balanço do Século. Lisboa: Imprensa Nacional-Casa da Moeda, 1990, pp. 89-94. Cf., também, na mesma obra, Fernando Gil, "A Inteligibilidade como Problema", pp. 11-22.

5 Provas, ed. cit., p. 24.

6 Ibid., p. 29.

${ }^{7}$ Fernando Gil e Mário Vieira de Carvalho, A 4 Mãos. Schumann, Eichendorffe outras notas. Lisboa: Imprensa Nacional-Casa da Moeda, 2005. 
a transformação formal estão para lá da linguagem", tal como a perspetiva de que o "real da música é o que não há nas palavras", justamente porque se lida com o inexprimível, como se os sentimentos "originários" não dispusessem de uma expressão artística fora da música, tudo isso, repetimos, é uma vertente na reflexão de alguém que sabe que a poesia e a música são formas de pressentir o inexprimível. Assim, para além da necessidade de apurar conceitos e argumentos, há também a convicção de que há um inexprimível na vida que a poesia ou a música deixam pressentir. Ora, este "espírito musical" assume múltiplas facetas, desde a referência às pequenas perceções do autor de Novos Ensaios sobre o entendimento humano, até ao que Leibniz, ainda ele, escreve sobre o belo enquanto suplemento da existência.

Há assim, parece-nos, dois eixos que assinalam a reflexão filosófica de Fernando Gil. Se por um lado encontramos uma vocação enciclopédica, atenta às controvérsias, às mediações e às aporias, temos, por outro, a presença do inexprimível e um incessante "questionamento às avessas", vertente na qual há um "não sei quê" que a filosofia tem a humilde tarefa de tentar compreender.

3. Sem perdermos de vista estas duas vertentes, o nosso intuito é o de nos centrarmos nas noções de alucinação e de identidade pessoal. Tentemos, por isso, seguir o rasto de um ensaio de Fernando Gil intitulado "En deçà de l'existence et de l'attribution, l'hallucination" (1994). ${ }^{8}$ Trata-se de pensar as noções de existência, evidência, crença, alucinação, retomando autores incessantemente convocados por Fernando Gil para alicerçar a sua reflexão.

De facto, o autor retoma Kant, Husserl e Wittgenstein para repensar a noção de existência e confrontá-la com a doutrina freudiana de juízo. O horizonte em que esta reflexão se circunscreve considera, via Freud, que "a alucinação é o operador natural da evidência." Contudo, em vez de "evidência", o autor fala em "crença", sem perda de sentido, pois a evidência é uma forma de crença absoluta. Acresce que a crença, tal como a evidência, prescindem da prova.

Neste contexto, o que ressalta é a preocupação com o aquém da existência. É aí que se encontra a crença-mãe (Urglaube) ou a proto-doxa (Urdoxa) husserliana. "Situada antes do juízo - escreve Gil, retomando Husserl -, a crença-mãe não se deixa enunciar". ${ }^{9}$ É este solo que "não se deixa enun-

8 In: La filiation de la foi et de la raison, coordenado por Claude Melman (Paris: Climats, 1994). Traduzido por Maria Luísa Couto Soares, "Aquém da existência e da atribuição: Crença e alucinação", em Fernando Gil, Modos de Evidência. Lisboa: Imprensa Nacional-Casa da Moeda, 1998, pp. 3-14.

${ }^{9}$ Modos de Evidência, ed. cit., p. 4. 
ciar" que assume o estatuto de uma evidência incontestável e se pressupõe em toda a atividade do conhecimento. Não há, assim, juízo que não assente numa posição pré-reflexiva, antepredicativa, do mundo. Trata-se, por isso, de uma fé primordial.

Ora, o nome freudiano dessa fé é "ficção", mesmo que sem o seu pendor antepredicativo. Ela constitui uma "alucinação primitiva" que se aparenta à fé percetiva husserliana. A sua estranheza não obsta à sua evidência, justamente devido à sua "força irresistível". E é neste contexto que Gil pode enunciar a sua hipótese de trabalho: "Crer na existência é o próprio conteúdo da crença e não se pode crer senão no verdadeiro porque a existência é por definição verdadeira". ${ }^{10}$

Convocados Husserl e Freud, Fernando Gil relembra Kant, em particular uma nota dos Paralogismos da Razão Pura para considerar que há, na Crítica da Razão Pura, uma referência à existência pré-categorial - "uma existência pré-categorial a montante do próprio juízo de existência".

No entanto, é necessário remontar a Freud e analisar a distinção que este estabelece entre juízo de atribuição e juízo de existência. Em "A Negação", Freud analisava o juízo de atribuição partindo de um eu-prazer que identifica a afirmação com o ingerir do bom e a negação com a expulsão do mau. Uma vez mais, o autor relembra Husserl para mostrar que as duas posições, a de Freud e de Husserl, não se confundem. Digamos desde já, antes de outras considerações mais pormenorizadas, que se para Freud "afirmação e negação são posições originárias", para Husserl elas são "secundárias", ou seja, "procedem de uma posição logicamente precedente." Também para Wittgenstein "o estado-de-coisas do Tratactus é uma figura homóloga da existência pré-categorial da aperceção kantiana e da Setzung (posição) husserliana do sentido"."1

4. Num segundo momento da sua reflexão, Fernando Gil retoma "A Negação" como texto pivot e debruça-se sobre a noção de eu-real. Embora haja nuances importantes sobre o sentido deste eu-real - em que seria necessário pôr em confronto o texto sobre "Pulsões e destino das pulsões" e também o Resumo da psicanálise - assinalemos os aspetos fundamentais. E esses são, seguramente, a conviç̧ão de que a perceção é, para Freud, definida como um reencontro. Melhor: "A perceção reconstitui sob uma outra forma o regime alucinatório em ação no eu-real inicial, um regime no qual «a existência da representação é já um garante da realidade do representado» (citação de

\footnotetext{
10 Ibid., p. 5.

11 Ibid., p. 8.
} 
"A Negação")." Percebe-se então a importância destas considerações no contexto da reflexão de Fernando Gil, a saber: se a perceção reencontra o objeto é como se ela fosse a "plena realização da alucinação." Daí a expressão: "A alucinação não é uma perceção sem objeto, mas é a perceção que é uma alucinação com um objeto". ${ }^{2}$ Vê-se, assim, que Gil quer defender que o sentido originário é a crença numa existência primordial, acabando por acrescentar que a filosofia e a psicanálise se elucidam mutuamente.

$\mathrm{Na}$ nossa leitura, a alucinação assinala esse transbordar da perceção, ou seja, sente-se/pensa-se sempre mais do que aquilo que se dá aos órgãos dos sentidos ou é intuído pela consciência. ${ }^{13}$ Ora, parece-nos que também o sentimento de si se deixa circunscrever por esse excesso que prende a alucinação ao conhecimento de si. Assim, ao pensar-se / sentir-se, o sujeito reúne a experiência de si, a vivência temporal, de forma a transbordar, quer dizer, a pensar-se e a sentir-se mais do que é em cada agora. Contudo, como veremos posteriormente, há efetivamente uma unidade que é peculiar à autoconsciência, de tal forma que o sujeito se vê de imediato como um eu. Ora, é esse pronome pessoal que parece irremovível. ${ }^{14}$ De qualquer forma, a alucinação é um operador: "De modo geral, chamaremos operador a todo o dispositivo específico de transformação, e deste modo a alucinação transformará um dado sensorial e linguístico em inteligibilidade, e a inteligibilidade em satisfação do espírito". ${ }^{15}$ Acresce que a natureza deste operador - escreve Fernando Gil seguindo Bion -, reside "no modo de apresentação de uma existência indeterminada enquanto tal ". ${ }^{16}$

5. Retomemos e aprofundemos o ensaio de Fernando Gil que procurámos sintetizar. Poderíamos, no entanto, começar por mencionar Proust, um autor que, salve melhor opinião, Fernando Gil pouco refere em toda a sua obra.

"Como se as nossas mais belas ideias fossem músicas que voltassem sem nunca as termos ouvido." É assim que escreve o narrador de $\dot{A}$ Procura do Tempo Perdido quando se encontra na biblioteca do palacete dos Guermantes. Trata-se de um momento invulgarmente belo, pretexto para o narrador reunir as suas últimas impressões e despedir-se do leitor. Mas há mais, muito mais. E não apenas a mestria com que se fala de um presente puro, alheio ao fluir

12 Ibid. p. 10.

${ }^{13}$ Cf., por exemplo, Fernando Gil, Tratado da Evidência. Lisboa: Imprensa Nacional-Casa da Moeda, 1996, p. 217.

${ }^{14}$ Cf. Strawson, "The first person - and others". In: Self-Knowledge, edited by Quassim Cassam. Oxford: Oxford University Press, 1994, pp. 210-215.

${ }^{15}$ Tratado da Evidência, ed. cit., p. 220.

${ }^{16}$ Ibid., p. 223 (itálicos no texto). 
da temporalidade porque capaz de criar instantes que se despregam do devir. A vida toda acaba por se deixar traduzir nesses instantes involuntários, proeza da memória e das leis profundas que a caracterizam. Esses pedaços de intemporalidade, como um lance de magia do próprio tempo, são acontecimentos que escrevem a sua lei e que indivíduo algum não há-de certamente deixar de sentir.

A sua força só pode brotar da intensidade das sensações, nunca dessa capacidade que merece o desdém do narrador da Recherche e que é designada como inteligência. Cada vez que a inteligência sobrevoa as impressões e as reminiscências, e despreza assim a forma como a vida se inscreve em cada sujeito, há um distanciar em relação à arte, pois só ela, como diria também o jovem Nietzsche, é a atividade metafísica por excelência. Só a arte pode dar conta das sensações, quer dizer, de tudo aquilo que a memória há-de reter sem saber ao certo porquê. A inteligência, enrijecida por leis lógicas, acaba assim por negar essa aventura que cada indivíduo deve decifrar e singularizar.

O livro subjetivo, como escreve Proust, é então um ato criador que não admite colaboradores nem suplentes. Mas é este o único livro que a realidade imprimiu e que nos dá o direito de zombar dessa literatura pretensiosa que pretende ser uma descrição das coisas através do aperfeiçoar de uma técnica. Mais do que técnica é de visão que se trata, para além de jamais podermos descrever as coisas que, de uma maneira ou de outra, não tivessem imprimido em nós as suas impressões. Se devemos "aprumar o oblíquo monólogo interior", é porque passamos uma vida a esconder-nos numa erudição que é apenas um sinal do fracasso da inteligência em dar conta do mais intenso em cada um: as suas impressões e reminiscências, ou seja, a maneira com que a vida se inscreve efetivamente em cada indivíduo. É assim que arranjamos sempre pretextos para nos afastarmos do livro subjetivo. Ora são os hábitos e os acontecimentos exteriores, ora a vertiginosa erudição de alguns e a capacidade de abstração de outros. Se a arte nos aproxima de nós, é porque cada um está próximo de si, ou seja, só ela é capaz e deve dar testemunho das impressões. Ao desmanchar a inteligência e o hábito, é tarefa da arte mostrar tudo aquilo que pode haver de superficial na inteligência, embora esta seja capaz de se servir de inúmeros subterfúgios, tantos que chega a fingir que é profundo aquilo que não passa de uma mero arranjo de palavras.

Do livro subjetivo ao facto de cada um ser leitor de si mesmo, vai um passo curto. Num caso e noutro, o que se sublinha é que tudo existe no espírito, o que está muito longe de mostrar um presumível idealismo por parte de Proust. Com efeito, não pode existir idealismo para quem defende com tanta convicção as sensações e a forma como a memória vai tecendo as suas figuras. E é esta forma involuntária que indica que não há indivíduo que seja livre perante a obra de arte. A inteligência pode ter sonhos de liberdade, defender o 
livre-arbítrio e enaltecer a capacidade de decisão do indivíduo, mas nada disso arranha a convicção proustiana de que estamos sempre atrasados em relação ao que vamos sentindo e às formas como a memória alucina, selecionando impressões e reminiscências.

Ora, é esta crítica em relação à inteligência e o elogio concomitante do que se sente que nos recorda o texto de Freud: "Die Verneinung" (1925). ${ }^{17}$ Com efeito, um dos enigmas da vida mental, tanto para Proust como para Freud, é a forma espontânea como as ideias se associam. Como é que, espontaneamente, construímos determinadas representações dos objetos? Há associações que emergem e, de imediato, são recusadas, como se o único papel que possuíssem fosse o de aparecerem no palco da mente para serem escorraçadas. Deste modo, podemos recusar certas representações, censurando-as de serem disparatadas e absurdas. Ao ficarmos surpreendidos, apressamo-nos a dizer que não tem sentido algum as representações ou a associação de representações que acabaram de invadir a nossa vida mental. Como se fossem estranhas e tratássemos de as expulsar da mente.

Mas Proust dá-nos também alguns exemplos que indicam a presença em nós de uma série de representações, hóspedes ruidosos e inesperados que nos surpreendem e acabamos por receber com hospitalidade. Ao tropeçar num movimento irregular ou ao ouvir o ruído de uma colher num prato, o narrador de $\dot{A}$ Procura do Tempo Perdido, confessa que esses pequenos acontecimentos desencadearam uma série de sensações dificeis de suster. São, na verdade, sensações que são signos de outras sensações, como se todas elas dessem as mãos e amarrotassem o presente e o passado no mesmo gesto. Esta cascata de representações que, subitamente, pode irromper na vida mental, é aquilo que singulariza o existente que cada um é.

Freud, sem discordar de Proust, em vez de acentuar a forma como as sensações/representações se desenrolam na mente a ponto de singularizarem o indivíduo pela satisfação que ocasionam, atende também a outra dimensão: ao facto de haver representações que são negadas devido ao desprazer que desencadeiam. Quase apetece dizer que se o indivíduo, em Proust, fica surpreendido com as coisas boas que tem dentro de si, para Freud essa surpresa deveria dirigir-se para as coisas más que existem em cada um e que, de imediato, se rejeita. Freud fala, aliás, da separação entre a função intelectual e o processo afetivo. Se se aceita, por um lado, uma representação, isso é feito para negar o processo afetivo subjacente. E é neste contexto que Freud refere a tendência do eu primitivo, guiado pelo princípio do prazer, para interiorizar o bem ou, ao

17 As nossas referências remetem para Freud: "La negación". In: El Yo y el Ello. Madrid: Alianza Editorial, 1980. Cf., também a tradução francesa em Résultats, idées, problèmes. Paris: PUF, 1984. 
invés, expulsar de si o mal. Nada compreenderemos do juízo se não tomarmos em consideração a tendência primitiva do eu que tende a interiorizar ou a expulsar o que, respetivamente, considera bom e mau.

Ora, é justamente esta camada primitiva do eu que acaba por conduzir à formação do juízo e, por conseguinte, à função intelectual que o define. Só que este, longe de ser a mera tradução em representações de uma perceção inicial, é antes uma forma de reativar e reencontrar uma realidade que já se encontra dentro do sujeito. Se para Proust o que conta é a vida mental, para Freud isso significa que a ideia que formamos da realidade é pré-determinada pela representação que temos dela. Neste sentido, a realidade confirma o que existe na representação, como se toda a perceção fosse a confirmação de uma representação primordial.

Deste modo, se a perceção não é um processo passivo, como acabámos de ver, é porque ao percecionarmos há já toda uma dinâmica da representação dentro do indivíduo. A relação que o narrador da Recherche tem com Albertina, uma das mulheres por quem se apaixonou, confirma este pressuposto. Confirma, ainda, o estatuto da negação tal como o expusemos. Se Albertina tem que, de algum modo, existir já dentro do narrador para poder então ser amada, isso é confirmado pela ideia de reencontro. Amar é, na verdade, um reencontro, como se a perceção se limitasse a alucinar, preenchendo e satisfazendo expectativas primitivas. Daí a consonância entre Proust e Freud: o real, entendido como aquilo que existe fora de nós, tem que começar por existir dentro de nós para ser efetivamente real.

6. Consideremos com mais atenção esse pequeno grande ensaio que é Die Verneinung. O psicanalista extrai "o puro conteúdo da ideia" quando o paciente nega uma determinada associação de ideias. Assim, a interpretação do psicanalista não se deixa iludir pela negação, pela qual o paciente apresenta as suas ideias. Melhor: as ideias surgem-lhe e, de imediato, nega-as, considerando-as despropositadas ou falsas. Para Freud isso prova a contrário: há um conteúdo que o psicanalista deve reter, embora se apresente sob a forma da negação. Trata-se, por isso, de uma denegação.

"O conteúdo da representação ou do pensamento, recalcado, pode então desbravar uma passagem até à consciência, na condição que se deixe denegar." Freud fala então da separação entre a "função intelectual e o processo afetivo". Como? Já o dissemos: o indivíduo aceita que o recalcado venha à consciência, mas trata-se tão-só de uma aceitação "intelectual”, pois o conteúdo afetivo é negado. Há apenas uma aceitação intelectual do recalcado.

Numa segunda etapa de Die Verneinung, interessa a Freud esclarecer o que entende por uma função do juízo: algo que nega ou afirma conteúdos de 
pensamentos. De facto, se não compreendermos as funções dos juízos não poderemos avançar na compreensão da realidade. Os juízos são representações que atestam ou negam a existência de algo na realidade. Esse atestar - ou afirmar - é interpretado, na "linguagem das mais antigas pulsões orais", como um comer, ou seja, uma introjeção. Essa é uma das funções do juízo.

Compreender melhor o que se entende por juízo é ver a ligação entre o eu-real definitivo - que se preocupa com a existência real de uma coisa representada - e o eu-prazer. Ora, a reformulação da noção de juízo leva Freud a considerar que é essencial saber que aquilo que se encontra em mim na qualidade de representação "pode também na perceção (realidade) ser reencontrado." É neste contexto que aparecem as ideias fundamentais: "Na origem, a existência da representação é já uma garantia da realidade do representado." O pensamento tem a capacidade de presentificar qualquer coisa "percebida uma vez", isto por intermédio da representação, mesmo que o objeto já não necessite de estar presente. Escreve ainda Freud: "O objetivo inicial e imediato da prova da realidade não é então o de encontrar um objeto, correspondente ao representado na perceção real, mas de o reencontrar, de se persuadir que está ainda presente." E Freud continua afirmando que "a reprodução da perceção na representação nem sempre é a sua fiel repetição: ela pode ser modificada por omissões, alterada por fusões de elementos diferentes. A prova de realidade tem então que controlar até onde se estendem estas deformações. Todavia, reconhece-se como condição de instalação de prova de realidade, que estejam perdidos os objetos que outrora procuraram uma satisfação real."

Relembremos duas ideias de Fernando Gil no Tratado da Evidência que nos permitem sintetizar o que dissemos sobre Proust e Freud. Uma que considera que o desejo segue o modelo da alucinação primitiva, a outra que "mais do que a alucinação ser uma perceção sem objeto, é a perceção que visa preencher a alucinação". ${ }^{18}$

7. De facto, em 1911, nas "Formulações sobre os dois princípios do funcionamento mental", Freud relaciona desejo e alucinação. Começando por referir a neurose e o sonho, afirma que se o indivíduo está inicialmente submetido ao princípio do prazer, terá, posteriormente, de alterar o aparelho psíquico para dar conta do mundo real. Por conseguinte, passar do agradável ao desagradável; do princípio do prazer ao mundo real, provoca alterações significativas no aparelho psíquico. Ora, é a alucinação que nos possibilita enfrentar aquilo que existe de desagradável na realidade, ou seja, é pela alucinação que lidamos com o mundo real para não defraudarmos o princípio do prazer. De facto, este princípio serve-se da alucinação para enfrentar o mundo real.

18 Tratado da Evidência, ed. cit., p. 228. 
A alucinação é então o que nos permite "substituir" o prazer ao mesmo tempo que permite defendermo-nos contra a insatisfação que o mundo real ocasiona. Vale mais um prazer alucinado que a ausência de qualquer prazer. Compreende-se assim que os sonhos sejam alucinações, ou antes, são pensamentos apresentados de forma alucinatória. Mas também o artista ou a criança se defendem alucinando. A criança, por exemplo, se não recebe por parte da mãe os cuidados que sente merecer, alucina a satisfação dessas necessidades. Mas o que é curioso é o facto de Freud, em 1911, pensar a consciência, a atenção e a memória como aquilo que solidifica a realidade, embora não possamos esquecer o carácter primordial do prazer e a alucinação concomitante. Acresce que o próprio pensamento, com a introdução do princípio da realidade, é capaz de se manter livre (da realidade) fantasiando. Deste modo, o pensamento (que sonha, brinca ou cria) mostra que não está totalmente dependente do mundo real. Dir-se-á então que, embora sob o domínio do princípio da realidade, a alucinação salvaguarda o princípio do prazer.

8. Retomemos Fernando Gil e interroguemo-nos: como se relaciona as reflexões do autor em torno da alucinação e da evidência com a identidade pessoal? Como poderemos nós refletir sobre a vertente conceptual da sua filosofia, atenta ao esclarecimento de conceitos e à rede que estes formam, com o que existe de inapreensível na singularidade de cada indivíduo? Numa palavra: como podemos relacionar a mais extrema das racionalidades com esse "não sei quê" que Leibniz referia e que atesta um fundo de irracionalidade inevitável?

"Eu" 19 é um ensaio que começa por assinalar o que há de problemático e de significativo no eu. Trata-se, por conseguinte, de iniciar uma reflexão considerando que o tema é não só problemático rc no significativo, o que justifica a atitude filosófica enquanto tal. Poderíamos filosofar sem problemas e sem uma ânsia de significação? De maneira nenhuma, pois é o problema e a necessidade de lhe dar uma ou várias soluções que nos faz pensar. $O$ espanto, que para muitos - como Platão ou Aristóteles - é o que nos incita a filosofar, só tem sentido dentro do horizonte mais vasto do carácter problemático do mundo e do significado que the atribuímos. Ora, se assim é, importa definir "problema" e "significação", ou seja, pensar aquilo que faz problema no problema e é significativo na significação. Mais do que uma mera redundância, o que se pretende é mostrar que a forma como se encara o "eu" enquanto problema e enquanto significação é uma atitude específica do discurso filosófico - é isso, justamente, que indica como a filosofia encerra uma incompletude

19 Texto inserido em Fernando Gil, Modos de Evidência, ed. cit. pp. 31-49. 
congénita. Se a natureza do discurso filosófico é desta natureza, seria então de todo o interesse pensar os operadores de evidência que acionam o jogo interminável da argumentação e da contra-argumentação.

Para Fernando Gil, o problema do "eu" reside na "desconformidade entre o sentimento da unidade da consciência [...] e a dificuldade, se não a incapacidade, de determinar um pólo «estável» de tal unidade". ${ }^{20}$ No que diz respeito às significações, ela surge do facto do "eu se enunciar pelo pronome pessoal", ou seja, "aperceber-me na qualidade de sujeito significa ter consciência de mim." Acresce que sou "sujeito da experiência que tenho da minha própria vida", o que significa a passagem de um sujeito consciente de si para um sujeito que tem uma vida. A evidência deste problema e destas significações é, ela mesma, uma forma de circunscrever a reflexão ulterior de Fernando Gil no ensaio que estamos a citar.

9. “O eu é um sentir que acompanha todas as modalidades da vida psíquica", escreve Fernando Gil, ${ }^{21}$ sublinhando assim o facto de o "eu" se desenhar enquanto experiência, algo que me acompanha, ou então, para dizê-lo kantianamente, uma representação que acompanha todas as representações e permite unificar a consciência. Contudo, importa a Fernando Gil, no início da sua reflexão, mostrar que a minha experiência se traduz na minha vida, impulsionando uma "adesão a si". É "esta adesão a si" que constitui uma ideia fundamental para compreender o self. Acresce que o self se deixa pensar como alguém, um indivíduo, a quem se atribui desejos, crenças, experiências ou ações. ${ }^{22}$ No entanto, importa primordialmente saber aquilo que, no indivíduo, possibilita tomar consciência desses estados e unificá-los. É isso que permite pensar o self a partir da primeira pessoa, ou seja, o facto de alguém ser sujeito das suas experiências, crenças, sensações e aí por diante. Podemos, aliás, relembrar uma vez mais Kant e os Paralogismos, em particular a ideia de reanalisar a substancialização do eu. Com efeito, para Kant o eu não pode ser uma substância, justamente porque não pode ser definido como tal. E porquê? Porque seria circular aplicar as mesmas categorias ao eu e àquilo que é por ele determinado. Se o eu é determinante e não determinado, é isso que merece a nossa atenção.

Ora, como compreender o aderir a si que Fernando Gil realçava? Donde surge esta forma de me aferrar (Sá de Miranda), que se traduz na primeira pessoa e em pronomes possessivos? Aquilo que é meu é, justamente, este eu

20 Ibid., p. 31.

21 Ibid., p. 32.

22 Cf. Kirstie Morrison, "The Self". In: A Companion to the Philosophy of Mind, edited by Samuel Guttenplan. London: Blackwell Publishers, 1995, pp. 550-558. 
que dura e faz da vida a minha vida e não a de qualquer outro. Percebe-se que a adesão a si não tem um cunho meramente epistemológico, antes visa uma satisfação em ser um si mesmo ${ }^{23} \mathrm{e}$, ainda mais do que uma satisfação, uma presença do indivíduo a si próprio que faz dele um eu. Ora, é ainda Fernando Gil, na mesma página em que começa por referir esta "adesão a si mesmo" que considera que "a primeira verdade alucinatória será a verdade do eu enquanto princípio de toda a verdade possível." Por conseguinte, o indivíduo adere a si mesmo de forma alucinada, o que se deve entender que a presença de si a si próprio é dada como a permanente presença de uma ausência. Uma vez mais, a alucinação, nesta perspetiva, não é a perceção de algo ausente mas sim a presentificação de uma ausência, ou seja, uma ausência que se realiza. É necessário, parece-nos, pensar melhor este aderir a si (que significa?) juntamente com esta alucinação de si próprio (o que há de ausente em cada presença?). Aderir a si é aproximar-se e familiarizar-se consigo próprio, mas tal é feito tornando presente alguma coisa que prima pela ausência, ou melhor, a realidade do eu dá-se tornando presente aquilo que, nesse eu, está ausente. Recordemos que "a primeira verdade alucinatória será a verdade do eu enquanto princípio de toda a verdade possivel."

"Mas esta análise é insuficiente", escreve Gil. ${ }^{24}$ Regressa, portanto, aos conceitos do eu: Uma consciência pontual de si, a consciência da interioridade e uma experiência de si, são conceitos do eu, facetas que "realizam um aprofundamento sucessivo do eu." Ora, a experiência de si é diversificada: é uma identidade, é qualitativamente uma experiência própria, para além do eu se experienciar como agente e sujeito volitivo e sentir a intransmissibilidade de um sentir as experiências. Na reflexão de Fernando Gil, assinala-se assim que a unidade do eu não se pode resumir ao pensamento mas sim ao fazer $\mathrm{e}$ ao sentir. Se o "eu" é uma forma, é também uma "permanência temporal, da posse de si, do agir e do padecer." Ou então: "o eu é uma forma ativa sentindo-se e transportando-se a si mesma". ${ }^{25}$

Sobressai neste conjunto de reflexões que sintetizamos de forma rude, a ideia de permanência. De tal forma que a própria adesão a si não seria pensável "sem o sentimento da duração". Reconheço-me na minha vida porque tenho uma experiência, algo que não se resume a acontecimentos instantâneos, mas assinala uma linha ininterrupta dos vividos - uma duração, portanto. Mas até esta merece ser reanalisada, pois, não é verdade que tenho uma consciência imediata de mim, instantaneamente? Não é verdade que esse é o acesso direto

${ }^{23}$ Cf. o nosso livro Identidade Pessoal. Lisboa: Instituto Piaget, 2003.

${ }^{24}$ Modos de Evidência, ed. cit., p. 33.

25 Ibid., p. 38. 
de mim a mim mesmo? Não teríamos, por isso, acesso à duração, ela remeteria para uma "ontologia inacessivel do tempo."

Contudo, não posso deixar de sentir a vida. A duração, mesmo que não seja um dado imediato da consciência epistemológica, é algo em que creio unificando passado, presente e futuro. O certo é que há uma crença na duração embora não seja possível prová-la. Vejamos então, acompanhando Fernando Gil, ${ }^{26}$ alguns aspetos que nos permitam, mais do que unificar as noções do "eu", assinalar os seus vértices:

a) Não consigo capturar, quer conceptual quer experiencialmente, quem sou.

b) A crença numa permanência pessoal é fortíssima, é ela que serve de suporte a outros dados. O eu constitui uma crença.

c) Se creio que sou um agente, "alguém" capaz de agir, é porque acredito que permaneço no tempo, ou seja, acredito que eu próprio, enquanto autor da ação, sou capaz de durar.

d) A adesão a si compreende-se a partir da noção de autoestima. O carácter afetivo da estima tem sido descuidado por perspetivas que tendem a intelectualizar o "eu". Por outro, a adesão a si enraíza-se na corporalidade.

e) "O sentimento de existir (cf. Rousseau) exprime uma aceitação da vida que é talvez a tonalidade humana da auto-organização biológica."

Posteriormente, em A Convicção ${ }^{27}$ no capítulo inicial - "Ser um sujeito" 28 a ênfase surge nessa relação entre "sujeito" e "consciência de si". Aliás, não é por acaso que a expressão de René Thom escolhida para epígrafe de $A$ Convicção seja: "Peut-on reconnaître autre chose que soi-même?". O acento agostiniano desta interrogação assinala a preocupação de Fernando Gil pela noção de sujeito e pela necessidade de a demarcar das teorias cognitivistas. Sem entrarmos nesta polémica - para a qual remetemos o leitor para o capítulo referido de $A$ Convicção - diremos tão-só que a consciência de si é a "forma incoativa da identidade pessoal". De facto, se a primeira se dá no instante, a segunda "realiza-se pela permanência do eu através do tempo." Deste modo, a consciência se si "é pura forma sem conteúdo", acabando o autor por defender que a unidade do eu resulta não tanto do eu penso cartesiano ou kantiano, mas de umfazer e de um sentir. ${ }^{29}$

\footnotetext{
26 Ibid., pp. 46-49.

27 Fernando Gil, La conviction, ed. cit.

28 Ibid., pp. 25-49.

${ }^{29}$ Ibid., p. 32.
} 
10. Desloquemos este conjunto de reflexões enxertando-os noutros textos de Fernando Gil, nomeadamente naqueles que dizem respeito à noção de belo. Em "Eu" não há nenhuma menção das questões estéticas, como se existisse uma preocupação estritamente filosófica em elucidar o que se entende por identidade pessoal. A não ser uma referência a Rousseau e ao "sentimento de existir", nada se diz sobre a forma como se poderá enxertar a identidade pessoal na experiência estética. Assim, também no "Belo como excesso de existir" nada se diz sobre a identidade pessoal. São textos com propósitos distintos. $^{30}$

Na qualidade de leitores podemos fazer a ponte entre um e outro. Como? Ao percecionar a realidade o que se procura é a verdade dessa realidade. Partindo de Leibniz e da infinita pluralidade das perceções, a verdade surge como uma harmonia das perceções. Há então um "suplemento", e ao suplemento desse suplemento, escreve Gil, seguindo Leibniz, chama-se beleza. Também em "Os Registos da Harmonia", 31 e ainda a propósito de uma reflexão sobre Leibniz se considera que a "harmonia e a semelhança se encaixam uma na outra em dois sentidos: a Harmonia é o efeito do conjunto das semelhanças - elas formam um todo ordenado - e a apreensão das semelhanças é já harmónica, ela consiste na determinação da unidade «na» variedade". ${ }^{32}$ Há, assim, um fio conceptual que une as noções de harmonia, semelhança, perfeição e belo. Se a perfeição permite a "elevação do ser" (Leibniz) - pois ela é "tudo o que pode fazer tanto quanto pode" - a beleza surge da entre expressão universal. Reconheçamos que o tom estético/metafísico destas reflexões permite-nos pensar que há algo de alucinado no encaixe entre a harmonia e a semelhança tanto quanto na elevação do ser que caracteriza a perfeição.

Ora, diremos nós, se o eu deve procurar a verdade, deve também, por maioria de razões, procurar ou encontrar a beleza. O nosso ponto de vista é que a identidade pessoal se fortalece ao tornar-se verdadeira e bela, ou seja, ao encontrar uma e outra. A duração, a experiência de si, a adesão a si, a ação, conceitos que encontrámos em "Eu", esteia-se agora na verdade e no belo. Sentimos, assim, a duração de outro modo se nos encontrarmos "dentro" da verdade; e a adesão a si é fortíssima quando sentimos o suplemento desse suplemento que é o belo. Poderia dizer-se que essas experiências contribuem

30 O ensaio "Eu" corresponde a uma comunicação ao colóquio "Aquém e além do cérebro". Porto: Fundação Bial, 1988. Pré-publicação em Análise, 20 (Lisboa, 1998). "O Belo como excesso do existir" (In: Modos de Evidência, ed cit., pp. 429-438), é a tradução de "Le beau comme excès de l'être: une note sur Leibniz". In: L. R. Santos, P. S. Alves e A. Cardoso (Dir.), Descartes, Leibniz e a Modernidade. Lisboa: Colibri, 1998.

31 In: Fernando Gil, Acentos. Lisboa: Imprensa Nacional-Casa da Moeda, 2005, pp. 165-179.

32 Ibid., p. 167. 
para o desapossamento de si. Sem dúvida. Mas lembremo-nos da diferença entre amour de soi e amour propre de Rousseau. Essa é a chave que nos permite compreender que a identidade pessoal se ganha quando se atinge uma experiência limite que o belo é pródigo em oferecer. Há portanto, a necessidade de se falar na sabedoria como algo que se bifurca na verdade e na experiência do belo.

Se seguirmos estes dois textos de Gil enxertamos o filosófico no estético. Elucidamos uma reflexão estritamente filosófica com uma reflexão estética. O ponto nodal em que ambos se cruzam enuncia-se do modo seguinte: existir, ter uma identidade, é durar e aderir a si de forma verdadeira e bela. Melhor: é quando encontramos a verdade e o belo ao longo de um existir insondável que é o nosso que podemos adquirir uma identidade. Essa identidade tem a ver com o que Rousseau chamava no Discurso sobre a origem e o fundamento da desigualdade entre os homens de amor de si mesmo, distinguindo-o do amorpróprio. Para ele, o amor de si mesmo é natural, e não exclusivo dos homens, pois os animais também o possuem. O outro, o amor-próprio, só pode surgir da sociedade, artificial e fictício como ela. Se há inocência no amor de si, no amor-próprio há comparação com os outros, interesse, vaidade, numa palavra: egoísmo. Sábio é aquele que venceu o amor-próprio em beneficio do amor de si, apercebendo-se que nada é, enquanto indivíduo, na economia do universo.

Mesmo sem nos aventurarmos nesse texto admirável que é as Rêveries du promeneur solitaire, fácil é ver como esse amor de si permite o sentimento de existência. E é neste sentido, justamente, que encontramos a identidade pessoal. Desde a noção de reencontro - via Proust e Freud - até às noções de belo e verdade, traça-se um dos eixos da nossa identidade, isso que não deixa de ser alucinado e que se dá como evidência absoluta. Mas a franja de indeterminação que percorre o eu não lhe retira o que nele há de insondável. Esse "sentimento confuso" (Malebranche), que Fernando Gil tanto gostava de citar, define a existência e faz-nos dizer, como Proust, que vivemos "como se as nossas mais belas ideias fossem músicas que voltassem sem nunca as termos ouvido." É isso que nos permite aderir a nós próprios, escrevendo o "livro subjetivo", alucinando e aprumando "o oblíquo monólogo interior". Afinal, é por aqui que pode despontar o que há de vago e de determinado no belo.

\section{ABSTRACT}

Fernando Gil's last philosophy, as exemplified in The Conviction, deals with the distinction between belief and conviction, as well as with the common features they both share. Such distinction relates to other distinctions: ground and foundation, ideology and truth, etc. Fernando Gil's main aim is the explanation of the intricate 
connections between the epistemic and the epistemological levels, that is between the relations the subject entertains with his beliefs and the relations those beliefs entertain with reality. In other words: his enquiry deals with the place of the subject in knowledge. 